\title{
Limitations of the Democratic Capacity of the Constitutional System of Bosnia and Herzegovina
}

\section{Davor Trlin}

Public Institution Center for Judicial and Prosecutorial Training in Federation of Bosnia and Herzegovina and Faculty of Economics and Social Sciences of the International Burch University, Sarajevo, Bosnia and Herzegovina

Email: davor.trlin@gmail.com

How to cite this paper: Trlin, D. (2017). Limitations of the Democratic Capacity of the Constitutional System of Bosnia and Herzegovina. Beijing Law Review, 8, 79-99. https://doi.org/10.4236/blr.2017.81006

Received: January 23, 2017

Accepted: March 19, 2017

Published: March 22, 2017

Copyright $\odot 2017$ by author and Scientific Research Publishing Inc. This work is licensed under the Creative Commons Attribution International License (CC BY 4.0).

http://creativecommons.org/licenses/by/4.0/ (c) (i) Open Access

\begin{abstract}
In this paper, author tries to emphasize the fundamental characteristics of the positive-legal status of political regime of Bosnia and Herzegovina. Bosnia and Herzegovina has applied the model of consociational democracy (all four elements: grand coalition, mutual veto, proportionality and segmental autonomy) which excludes effective participation of citizens in decisionmaking. The constitutional structure of Bosnia and Herzegovina is dominated by direct democracy. It is also based on the fight of political elites. The paper discusses perspectives of direct democracy in Bosnia and Herzegovina. This paper also focuses on the possibility of merging the civil and ethnic in the functioning of constitutional-political system of Bosnia and Herzegovina. An analysis of the democratic potential of the two most important state bodies for the implementation of any democracy-legislative representative body and the constitutional court will be made.
\end{abstract}

\section{Keywords}

Political Regime, Consociational Democracy, Constitution, Bosnia and Herzegovina, Direct Democracy

\section{Introduction}

We are in the midst of a strong confrontation in the socio-political system of Bosnia and Herzegovina in the context of majoritarian decision-making. Recent practices of direct democracy in Republika Srpska have revealed that there is a tension between an implementation of legal acts of Bosnia and Herzegovina by lower political-territorial units. Lower political unit, in this case Republika Srpska, answered with the form of direct democracy which is clearly unconstitu- 
tional (contrary to the Constitution of Bosnia and Herzegovina and to the case law of Constitutional Court of Bosnia and Herzegovina). The central theme for this article consists of one specific question: to what extent and by what mechanisms citizens should have a part in the decision-making process in heterogeneous federal states? The answer to this question is sought to provide in view of the legitimacy of the government, and concerning the way in which the legal norms in such a community are created and implemented. In this article, I will try to prove a thesis that consociational democracy, the democracy model currently applied in Bosnia and Herzegovina, should be replaced or supplemented by participatory model of democracy that would protect the individual and collective human rights, while also adequately protect the interests of the citizens and facilitate that their requirements are adequately taken into account by elected representatives. In response to the above mentioned issue, the normative framework in Bosnia and Herzegovina is presented, which narrows the ideals of the rule of law which is a prerequisite of any democracy, including the consociational, but also offered some normative solutions that could represent a balance between preventing the country to be efficient and managing tensions that occur in the Bosnia and Herzegovina's society. The significance of the research is the attempt to try to give an answer to a question of making the balance between civic and ethnic in Bosnia and Herzegovina, by allowing citizens to broader participate in decision-making. Also, the second aspect of social significance is a question of socio-economic progress of Bosnia and Herzegovina and what are the limiting factors of the constitutional system. Academic significance would be a fact that, no matter how rich a literature of political regimes of former Yugoslav republic in the domestic languages is, there is not plenty of it in English language. So, one of the aims of this paper is to give an insight to a specifics of constitutional system of Bosnia and Herzegovina to a community of international researches. The paper is actually made on the basis of the thesis which I presented on a lunch seminar at the Centre for Comparative and European Constitutional Studies of the Law faculty of the University of Copenhagen (Kingdom of Denmark), which I held on 25 January 2016 (discussant: assistant professor Ebrahim Afsah) ${ }^{1}$.

Bosnia and Herzegovina is a unique example of a modern representative democracy. The Constitution of Bosnia and Herzegovina is antinomic, because it contains mutually opposed sollutions ${ }^{2}$. Since its provisions cannot be unconstitutional, no one in Bosnia and Herzegovina can remove the antinomy and order the Parliamentary Assembly of Bosnia and Herzegovina to revise the Constitution. It is up to ethnic political elites to reach a consensus on constitutional revision. So far, only one amendment to the Constitution of Bosnia and Herzegovina has been adopted, and it is the one which determines the status of the Brčko

${ }^{1}$ URL (last checked 08 February 2017) http://jura.ku.dk/cecs/calendar/lunchseminarwithdavortrlin/. ${ }^{2}$ Basic antinomies are: the rule of law-the authoritarian state of ethnocratic type; democracyethnocracy; federal state-alliance of states; state sovereignty-holder of sovereignty: justice-injustice (See: Šarčević (2009). Dejtonski ustav: Karakteristike i karakteristični problemi. Sarajevo, KAS, 75-83). 
District of Bosnia and Herzegovina (it is a unit of local self-government under the direct sovereignty of Bosnia and Herzegovina ${ }^{3}$ ).

The Constitution of Bosnia and Herzegovina is very rigid and changing it so as to strengthen the democratic practice of the Bosnian and Herzegovinian institutions will be very difficult. In this paper, I will focus on eight elements which weaken the democratic potential of the constitutional system of Bosnia and Herzegovina. Some of these elements are a part of the political system, but are strongly related to the constitutional system. Relevant international organizations have already pointed them out in their reports, and international courts have made decisions about some of them and declared that parts of the $\mathrm{BiH}$ constitutional system are undemocratic because they discriminate against some categories of the people of Bosnia and Herzegovina (the demos, i.e. statepeople).

\section{Consociational Democracy}

According to Annex 4 of the General Framework Agreement for Peace, $4^{4}$ Bosnia and Herzegovina is established as an asymmetric state consisting of two entities, i.e. federal units, the Republic of Srpska and the Federation of Bosnia and Herzegovina, and a local government under the direct sovereignty of Bosnia and Herzegovina called the Brčko District of Bosnia and Herzegovina (Figure 1).

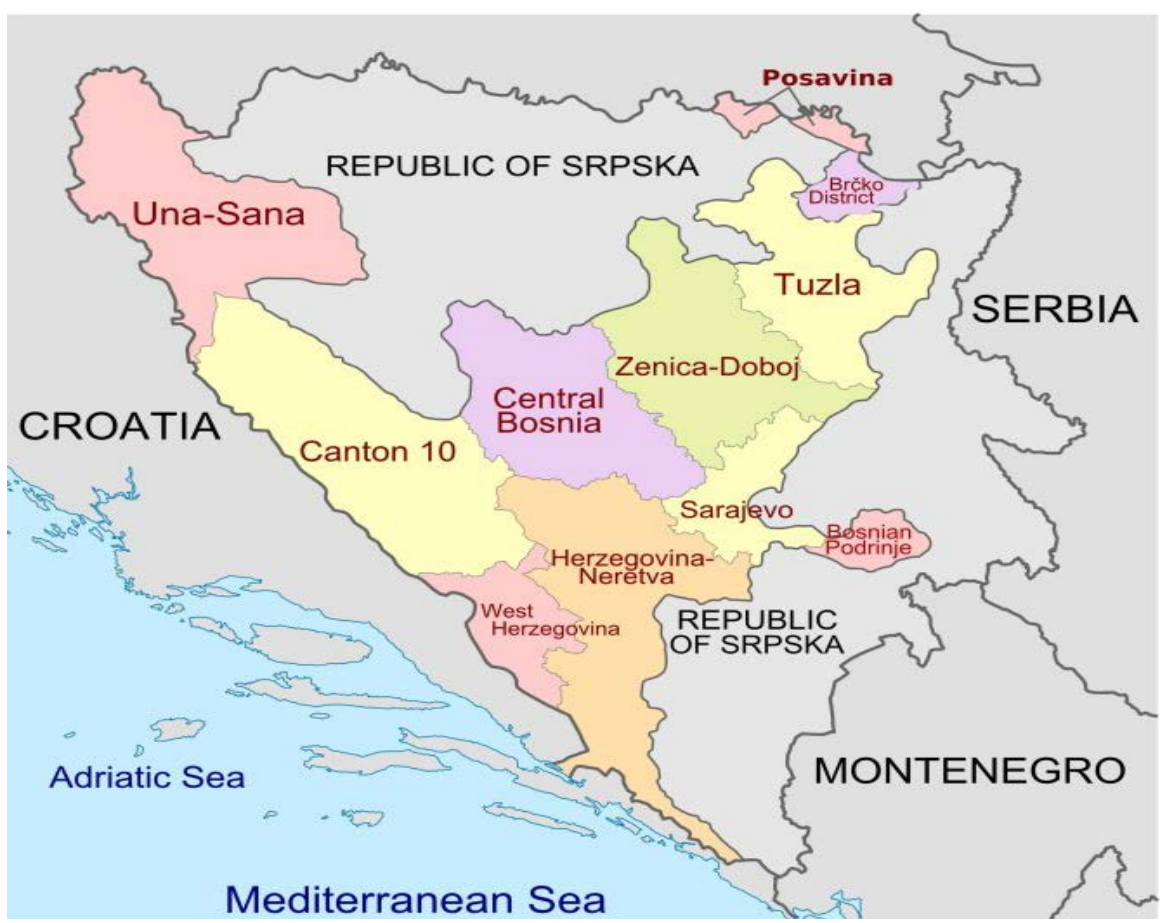

Figure 1. A map that displays the fractured nature of Bosnia and Herzegovina.

${ }^{3}$ It is not a third federal unit in the constitutional system of Bosnia and Herzegovina because it does not participate in exercising the state power in Bosnia and Herzegovina (See: Marković (2009a). Federalizam u ustavnom sistemu Bosne i Hercegovine. Ph.D. Thesis, Beograd: Beograd University, 234).

${ }^{4}$ It is the peace agreement reached at the Wright-Patterson Air Force Base near Dayton, Ohio, United States of America, in November 1995. It was formally signed in Paris on 14 December 1995. 
While the Republic of Srpska is a centralised entity, the Federation of Bosnia and Herzegovina is a power-sharing federation composed of ten cantons which functions on the basis of equality and equity of its federal units. In order to guarantee a state-level decision-making process, the state and the entities share a set of central state institutions pursuant to Annex 4 (the Constitution of Bosnia and Herzegovina ${ }^{5}$ ) of the General Framework Agreement for Peace ${ }^{6}$. These are: the three-member Presidency and the Council of Ministers of Bosnia and Herzegovina as the executive authority, the bicameral Parliamentary Assembly as the legislative authority, and the Constitutional Court, as the judicial authority. Each of these bodies, just like all other state institutions, is designed in strict accordance with the principles of consociational power-sharing and the tangible resources of strict ethnic lines providing proportional representation ${ }^{7}$ of the "constituent peoples" at all levels and positions. In addition, representatives of the "constituent peoples" have the ability to veto a vital national interest that allows them to block the proposals of laws or policies that they consider harmful to their people. This set of institutional checks and balances, grounded in the theory of consociation, was created in order to "guarantee the political representation of each ethnic group at the institutional level, in order to protect the right of groups to self-government, and to promote inter-ethnic accommodation and compromise" (Belloni, 2004). The structure established by the General Framework Agreement covers all four classical consociation criteria (Lijphart, 1977; Bose, 2002; Bieber, 2004; Marković, 2009b; Stojanović, 2009) a grand coalition through the participation of representatives of all major groups in the political decision-making; the autonomy of segments by giving three (constitutional) ethnic groups the right to perform certain duties determined by the constitution; proportionality through equal representation of ethnic groups; and the veto power enabling these groups to protect their "vital interest".

The constitutional system of Bosnia and Herzegovina is determined by the constituent peoples (Bosniaks, Serbs and Croats), the others, and the citizens ${ }^{8}$. The constitutionality of peoples is a collective right narrower than the right to sovereignty, but broader than the individual right to ethnic identity (Trnka, 2006). The constituent status of peoples does not result neither in the right to self-determination nor in the right to secede. Constitutionality of a particular people is not achieved independent of other people who have the same rights. Constitutionality implies mutual rights of all three peoples to regulate the constitutional order (together with the citizens and others) and to use all available mechanisms for the protection of ethnic equality.

\footnotetext{
5ك̌arčević (2009). Dejtonski ustav: Karakteristike i karakteristični problemi. Sarajevo, KAS, 60-61; Pobrić (2000). Ustavno pravo. Mostar, "Slovo", 19 (See also: Amendment I to the "Constitution of Bosnia and Herzegovina", Official Gazette of Bosnia and Herzegovina, No. 25/09).

${ }^{6}$ Articles IV - VI of Annex IV to the General Framework Agreement for Peace.

${ }^{7}$ Consociational democracy was discussed in works of Dutch political scientist Arendt Lijphart. He identified four key characteristics of consociational democracies: grand coalition, mutual veto, proportionality and segmental autonomy (See: Lijphart (1977). Democracy in Plural Societies: A Comparative Exploration, New Haven).

${ }^{8}$ Preamble of Annex 4 to the General Framework Agreement for Peace.
} 
At the signing of the General Framework Agreement for Peace in Dayton ${ }^{9}$ it was clear that Bosnia and Herzegovina would not be able to maintain the premises it was based on in the period from 1945 to $1990^{10}$. During the war in Bosnia and Herzegovina, ethnic ${ }^{11}$ identity became more important than before and three distinct subcultures (the Bosniak, the Serb and the Croat subculture) were formed. This segmentation of the Bosnian society demanded a constitutional balance of power among political ethnic elites, and the consociational mechanisms at the time seemed to the best option. The constitutional position of citizens who did not belong to any of the constituent peoples was not relevant to the political elites who participated in the Dayton negotiations and the signing of the agreement; their primary aim was to end the war, while the local politicians who were, in the end, the ones who wrote the Constitution of Bosnia and Herzegovina, have long since declared themselves only as the guardians of the interests of a single ethnic group, not of all the citizens of Bosnia and Herzegovina or of a fourth, fifth ethnic group. In Dayton, there were politicians who belonged to the so-called civic parties, however, and such parties have, in practice, turned out to be covert ethnic parties. Today, Bosnia and Herzegovina continues to operate as a country of ethnic ideology and personal interests which control the imaginary ethnic territories, interpret the political history of Bosnia and Herzegovina in different ways, and seek to continue the economic stagnation of Bosnia and Herzegovina, the lack of economic development and the existence of a strong class and social differentiation along the lines of ethnic homogenisation.

Consociational democracy in Bosnia and Herzegovina is enforced to the point of absurdity. This can be seen in the following constitutional provision: "Officials appointed to positions in the institutions of Bosnia and Herzegovina shall be generally representative of the peoples of Bosnia and Herzegovina." 12 Therefore, this means that elected officials are not representatives of the citizens but of the constituent peoples, and, in general, they do not represent the citizens who are non-constituent peoples (national minorities and ethnically undeclared people). These categories of people can have active and passive electoral rights in general elections for the Parliamentary Assembly and the Council of Ministers of $\mathrm{BiH}$, and if they meet the formal requirements, for the Constitutional Court, but elected officials have an obligation to be exclusively or primarily concerned with the interests of the constituent peoples. This stems from the fact that the Constitution of Bosnia and Herzegovina gives preference to entities and to the prin-

\footnotetext{
${ }^{9}$ Twenty-one year after the signing of Dayton peace agreement, Bosnia and Herzegovina is still formally under the extensive control of Office of High Representative (OHR), although this institution did not exercised largely its international public authority in recent years. OHR allowed domestic institutions to try to implement democratic reforms by themselves, which could be seen as democratic but also as a reason for stagnation in socio-economic progress of Bosnia and Herzegovina.

${ }^{10}$ Bosnia and Herzegovina was a part of Yugoslavia in that period, which can be characterized as a peaceful and prosperous. Bosnia and Herzegovina was an equal member of Yugoslav federation, with historical borders from medieval period of time. This federal unit was unitary and indivisible political community in which all ethnic groups had equal rights. By the words of constitution of the 1974 Yugoslav Constitution all power belonged to the "working class and working people".

${ }^{11}$ Factor that distinguishes the three ethnic groups is religion. Bosniaks are predominantly Muslims, Serbs are predominantly Ortodox Christians and Croats are predominantly Catholics.

${ }^{12}$ Annex 4, Article IX, Paragraph 3 of the General Framework Agreement for Peace.
} 
ciple of equal ethnical representation which does not correspond to the principles of parliamentary democracy (Šarčević, 1997).

\section{Limitations of Active and Passive Voting Rights}

In legal theory in Bosnia and Herzegovina, a predominant view is that Bosnia and Herzegovina at the central level of government adopted a semi-presidential (mixed) system of government or a semi-presidential political system. However, the semi-presidential system applied at the level of the central government in Bosnia and Herzegovina has a deformity in relation to the theoretical model of a semi-presidential system and compared to comparative constitutional law. Resting on the principle of separation of powers, a semi-presidential system requires such an organization of state authorities and relationships between them in which the main body of state power is the head of state. The basic premise of the superiority of the head of state is that this state body in a semi-presidential system has a concentrated democratic legitimacy, the will of the voters expressed in direct elections.

Even though Article II (4) ${ }^{13}$ of the Constitution of Bosnia and Herzegovina prohibits discrimination, according to the census of 1991, the citizens of Bosnia and Herzegovina (the Roma, Jews, Ukrainians, Slovenians, etc), or those who do not identify themselves with certain ethnic groups, cannot assume the positions discussed below. The Constitution of Bosnia and Herzegovina stipulates the following: "The Presidency of Bosnia and Herzegovina shall consist of three members: one Bosniak and one Croat, each directly elected from the territory of the Federation, and one Serb directly elected from the territory of the Republic of Srpska." Further on, Article V (1 a.), stipulates, "The members of the Presidency shall be directly elected in each Entity (with each voter voting to fill one seat in the Presidency) ...". Thus, the writers of the Dayton Constitution have made it impossible for Bosniaks and Croats who live in the Republic of Srpska, and Serbs living in the Federation, as well as all those who do not fall into the category of constituent peoples, to run for office for the position of member of the Presi-

\footnotetext{
${ }^{13}$ The Preamble of Annex 4 to the General Framework Agreement for Peace (the Constitution of Bosnia and Herzegovina) contains the following statement: "Recalling the Basic Principles agreed in Geneva on 8 September 1995 and in New York on 26 September 1995, Bosniaks, Croats and Serbs, as constituent peoples (along with others), and citizens of Bosnia and Herzegovina hereby determine that the Constitution of Bosnia and Herzegovina is as follows..." There is a contradiction in this sentence-all citizens are equal, but there are also the three peoples. State authorities of Bosnia and Herzegovina rest on: 1. the sovereignty of citizens, 2. the constituency of Bosniaks, Croats and Serbs, and 3. the position of other peoples, as well as the position of those who do not want to declare themselves ethnically. Bosnia and Herzegovina, therefore, can be characterised as an ethnocratic country. However, there is another contradiction in the normative part of its Constitution-Article II (4), and that is the prohibition of discrimination (the Constitution prohibits it using the provisions of the Universal Declaration of Human Rights and the European Convention for the Protection of Human Rights and Fundamental Freedoms: "The enjoyment of the rights and freedoms provided for in this Article or in the international agreements listed in Annex I to this Constitution shall be secured to all persons in Bosnia and Herzegovina without discrimination on any ground such as sex, race, colour, language, religion, political or other opinion, national or social origin, association with a national minority, property, birth or other status.") International documents for the protection of human rights and fundamental freedoms, which make up an integral part of the BiH Constitution, expressly prohibit discrimination on the basis of personal characteristics or status.
} 
dency of Bosnia and Herzegovina (and the House of Peoples of the Parliamentary Assembly of Bosnia and Herzegovina). It is also impossible for all these categories to have active suffrage. Persons who do not belong to one of the constituent peoples, Bosniaks, Serbs and Croats, and who reside in the Federation of Bosnia and Herzegovina, cannot choose a Serb member of the Presidency. Moreover, persons who belong to the three constituent peoples and others who do not belong to the constituent peoples, and have residence in the Republic of Srpska, cannot choose a Bosniak and Croat member of the Presidency.

It can be considered that not even the choice of head of state, as proposed in the so called "April package" of constitutional reforms ${ }^{14}$ in 2006, would lead to the fulfilment of these human rights. In the future, the Constitution should be revised so as to include universal and equal suffrage particularly regarding the ruling of the European Court of Human Rights in Strasbourg in the Sejdić and Finci v Bosnia and Herzegovina case ${ }^{15}$, the Zornić v Bosnia and Herzegovina case $^{16}$ and the Pilav v Bosnia and Herzegovina case ${ }^{17}$. Due to non-compliance of

\footnotetext{
${ }^{14}$ In the "April package" of constitutional agreements, which the Parliamentary Assembly of Bosnia and Herzegovina failed to ratify, an alternate membership of the Presidency was proposed with the aim to create a rotating position of the president and vice-presidents, and to give the Parliamentary Assembly the jurisdiction over nominating and electing members of the Presidency.

${ }^{15}$ According to this ruling, it has been found that there is violation of Article 14 in conjunction with Article 3 of Protocol No. 1 of the European Convention on Human Rights and Fundamental Freedoms, which refers to the inability of applicants to stand for election to the House of Peoples of the Parliamentary Assembly of Bosnia and Herzegovina, as well as a violation of Article 1 of Protocol No. 12 due to the inability of applicants to stand for election to the Presidency of Bosnia and Herzegovina. Apart from the European Court of Human Rights, numerous relevant international organisations have pointed out the method of electing candidates to positions in the constitutional and electoral system. See for example: the UN BiH and UN OHCHR, "Compilation of Recommendations of the UN Human Rights Bodies, Bosnia and Herzegovina", 5-8; Venice Commission, (2005) "Opinion of the Venice Commission on the Constitutional Situation in Bosnia and Herzegovina and the Powers of the High Representative", CDL-AD (2005) 004, 11-12 March 2005, footnote 4. ${ }^{16}$ The Court accepted the appeal of Azra Zornić, member of the Social Democratic Party, who complained that as a citizen of Bosnia and Herzegovina (she declared herself as a citizen of Bosnia and Herzegovina, and not as a member of a constituent people), she cannot be nominated for a position in the House of Peoples of the Parliamentary Assembly of Bosnia and Herzegovina and in the Presidency. The court found that her human rights have been violated, and confirmed its earlier stance in the Sejdić and Finci v Bosnia and Herzegovina case, by which Bosnia and Herzegovina has to allow all citizens active and passive voting rights or the right to elect and be elected. The court in Strasbourg, in its ruling in Case No. 3681/06, found that there had been a violation of Article 14 (prohibition of discrimination) in conjunction with Article 3 of Protocol No. 1 (the right to free elections) to the European Convention on Human Rights in relation to the applicant's inability to appeal to participate in elections for the House of Peoples. Also, it found that there had been a violation of Article 1 of Protocol No. 12 (general prohibition of discrimination) of the European Convention on Human Rights in relation to the impossibility of appellant Azra Zornić to participate in elections for the House of Peoples of Parliamentary Assembly of Bosnia and Herzegovina and the Presidency of Bosnia and Herzegovina. The Court therefore deems that the time has come to establish a political system that would allow all citizens to participate in elections for the Presidency and the House of Peoples of Bosnia and Herzegovina, without discrimination on the basis of ethnicity and without giving special rights to the constituent peoples at the expense of minorities and citizens of Bosnia and Herzegovina, which implies the need for changes in the Constitution.

${ }^{17}$ This is the third judgment of the ECHR in respect of Bosnia and Herzegovina concerning the violation of Article 1 of Protocol. No. 12 to the Convention. This judgment declared that the Constitution of Bosnia and Herzegovina is discriminatory in relation to its constituent peoples, when they want to stand for election to the Presidency of Bosnia and Herzegovina, in this particular case in relation to the Bosniaks in the Republika Srpska.
} 
the Constitution of Bosnia and Herzegovina ${ }^{18}$ and the Elections Act with the European Convention on Human Rights of by the European Court of Human Rights, the implementation of the ruling of the Constitutional Court in case No. U-14/12 (2015) is still pending ${ }^{19}$.

\section{Ethnic Quotas and Interests}

The Constitution of Bosnia and Herzegovina imposes a quota system for deter-

${ }^{18}$ There are three potential processes that we can follow in implementing the ruling in the Sejdić and Finci v Bosnia and Herzegovina case. The first principle is the minimum intervention principle. According to this principle, two members of the Presidency of Bosnia and Herzegovina would be elected from the territory of the Federation of Bosnia and Herzegovina, and the third one would be elected from the territory of the Republic of Srpska, but provisions regarding ethnicity would be removed, and only one member of the Presidency could simultaneously be a member of the same constituent people or member of "Others". In this model, the indirect election of delegates to the House of Peoples of the Parliamentary Assembly would be carried out through the caucuses of the constituent peoples and "Others" in the House of Peoples of the Parliament of Federation of Bosnia and Herzegovina and in the Council of Peoples of the Republic of Srpska, namely by electing an equal number of delegates from among "Others" from both entities. The second option of completing the membership of the House of Peoples by applying the minimum intervention principle would be to elect delegates to the House of Peoples directly. According to the optimum intervention model, the Parliamentary Assembly would elect members of the Presidency (one president and two vice-presidents), and “Others" could (indirectly) participate in the vote to elect members of the Presidency. Another option for a change in the way members of the Presidency of Bosnia and Herzegovina are elected in the optimum intervention model would be to have the Parliamentary Assembly elect one president and three vice-presidents out of which one would be from "Others". An optimum intervention in the House of Peoples would mean that the House of Peoples would represent the federal units, whereas the House of Representatives would represent the citizens. According to the maximum intervention model, a single President would be elected. Another option would be to abolish the institution of the Presidency of Bosnia and Herzegovina and to transfer its responsibilities to the chairpersons of Houses of the Parliamentary Assembly. A maximum intervention in the House of Peoples would be to completely discontinue the House of Peoples and move the competence over the mechanism for the protection of the vital national interest to the House of Representatives. Another maximum intervention that could be brought about would be to have only constituent people in the House of Parliament and no "Others" whatsoever. Such a solution, along with a simultaneous introduction of the possibility to elect people from "Others" President (which would require a change in the number of Vice-presidents), would not necessarily be inconsistent with the European Convention for the Protection of Human Rights and Fundamental Freedoms. In this regard, see: Venice Commission (2006) "Opinion of the Venice Commission on the draft amendments to the constitution of Bosnia and Herzegovina”, CDL-AD (2006) 019, 12 June 2006), para. 27.

${ }^{19}$ The Constitutional Court, on the 91st plenary session held on 26/27 March 2015, in case No. U-14/12 (2015), decided on the request of Željko Komšić (member of the Presidency of Bosnia and Herzegovina at the time of application) to review the constitutionality of certain provisions of the Constitution of the Republic of Srpska (1992), the Constitution of the Federation of Bosnia and Herzegovina (1994) and the Elections Act of Bosnia and Herzegovina, which, in the opinion of the applicant, were not in accordance with the provisions of Protocol No. 12 to the European Convention for the Protection of Human Rights and Fundamental Freedoms, provisions of the Constitution in conjunction with the International Convention on the Elimination of all Forms of Racial Discrimination, and the International Covenant on Civil and Political Rights. Namely, the applicant deemed that the provisions of entity constitutions, which require that presidents and vice-presidents come from the constituent peoples, are in violation of the Constitution of Bosnia and Herzegovina and the European Convention for the Protection of Human Rights and Fundamental Freedoms in relation to "Others", and that they are inconsistent with the decision of the European Court of Human Rights in the Sejdic and Finci v Bosnia and Herzegovina case, since they prevent "Others" from participating in the elections to hold public office positions on equal terms. The Constitutional Court has partially granted the request of Željko Komšić and found that Article 80, Paragraph 2, Point 4 (Point 1, Paragraph 2 of Amendment LXXXIII) and Article 83, Paragraph 4 (Point 5 of Amendment XL as amended by Point 4 of Amendment LXXXIII ) of the Constitution of the Republic of Srpska (1992), and Article IV.B.1, Article 1, Paragraph 2 (as amended by Amendment XLI) and Article IV.B.1, Article 2, Paragraph 1 and 2 (as amended by Amendment XLII) of the Constitution of the Federation of Bosnia and Herzegovina (1994), and Articles 9.13, 9.14, 9.16 and 12.3 of the Elections Act of Bosnia and Herzegovina, are not in accordance with Article II (4) of the Constitution of Bosnia and Herzegovina and Article 1 of Protocol No. 12 to the European Convention for the Protection of Human Rights and Fundamental Freedoms. However, the Constitutional Court will not abolish the above cited provision of entity constitutions and the Elections Act, i.e. it will not order the Parliamentary Assembly of Bosnia and Herzegovina, the National Assembly of Republic of Srpska and the Parliament of Federation of Bosnia and Herzegovina to incorporate the above given provisions in entity constitutions and Elections Act of Bosnia and Herzegovina to terminate the existing non-compliance of the Constitution Bosnia and Herzegovina and the Elections Act with the established by the European Court of Human Rights until constitutional and legislative measures to end the current inconsistencies of the Constitution of Bosnia and Herzegovina and the Elections Act of Bosnia and Herzegovina with the European Convention are adopted in the domestic legal system. The European Court of Human Eights has ruled that the Constitution and Elections Act of Bosnia and Herzegovina are inconsistent with the European Convention for the Protection of Human Rights and Fundamental Freedoms. 
mining the composition of the House of Peoples (Article IV/1), the appointment of the Chairman and Vice Chairman of the Houses of the Parliamentary Assembly (IV/3b), the composition of the Presidency of Bosnia and Herzegovina (Article V), and the first composition of the Governing Board of the Central Bank of and Herzegovina (Article VII, Paragraph 1, Item 2). The quota system is accepted in multiethnic federations such as Switzerland and Belgium. However, the difference between Bosnia and Herzegovina and Switzerland and Belgium is that the citizens of these two countries are not expected to vote based on their ethnic origin. Even though the framework of the Parliamentary Assembly of Bosnia and Herzegovina initiated specific activities aimed at changing the above mentioned constitutional solutions ${ }^{20}$, there still has been no change to the solutions that are contrary to international human rights documents. The potential that the ruling in the Sejdic and Finci v Bosnia and Herzegovina case offers is significant in the sense that it is an opportunity to eliminate the shortcomings of the constitutional and legal system of Bosnia and Herzegovina and its entities (Kulenović, Hadžialić-Bubalo, \& Korajlić, 2010) (numerous provisions in the constitutions and other legal acts in Bosnia and Herzegovina are not in line with the standards of the European Convention for Human Rights and Fundamental Freedoms), but at least minimal interventions will have to be made (European Commission, 2010) in order to satisfy the requirements that the rulings in the Sejdić and Finci v Bosnia and Herzegovina case and the Zornić v Bosnia and Herzegovina case have set.

The concept of protecting the interests of the constituent peoples does not involve just their adequate representation in the government of Bosnia and Herzegovina, but other mechanisms as well. Certain protection mechanisms in decision-making in the representative bodies in Bosnia and Herzegovina are incorporated in the constitutional system of Bosnia and Herzegovina, and they are, in practice, frequently used to block the functioning of the decision-making process (Venice Commission, 2005). The first such mechanism is the protection of the vital national interests of the constituent peoples which exists in order not to adopt decisions that are contrary to the interests of any of the constituent peoples. This mechanism is incorporated both in the Parliamentary Assembly as well as in the decision-making process in representative bodies in the Mostar City Council. In the parliamentary procedure, each of the caucuses in the House of Peoples of the Parliamentary Assembly may, by a majority vote of delegates in a caucus, declare that a decision is destructive of a vital national interest. The challenged decision is rejected by majority vote of each caucus. If any caucus opposes the challenged decision, the matter is discussed on the level of a joint

\footnotetext{
${ }^{20}$ The Parliamentary Assembly established a temporary joint committee of both Houses for the implementation of rulings of the European Court of Human Rights in the Sejdic and Finci v Bosnia and Herzegovina case (Conclusion on the establishment of this Commission was published in the Official Gazette of Bosnia and Herzegovina No. 81/11 as of 11 October 2011). The Commission was tasked primarily to prepare proposals for amendments to the Constitution and submit them to parliamentary procedure by 30 November 2011, and a Draft Act of Amendments to the Elections Act by 31 December 2011. However, a compromise on the revision of these acts was never achieved.
} 
commission composed of members of all caucuses. If they fail to reach an agreement, the Constitutional Court of Bosnia and Herzegovina gets involved in the process to examine the "procedural compliance of the case" ${ }^{21}$. The Constitution of Bosnia and Herzegovina does not define the "vital national interest". Therefore, the Constitutional Court interprets the meaning of the term on a case-by-case basis. Entity Constitutions give a detailed definition of the vital national interest, and thus, in practice, leave room for arbitrary interpretation of its meaning on the part of the political elites. Entity Constitutions stipulate that vital national interests are those listed in the text of the constitutions, but that any other matter is also a vital national interest if $2 / 3$ of one of the caucuses claims ${ }^{22}$ so, which leads to the conclusion that any matter can be declared a vital national interest. It should be noted that the Constitutional Court of the Republic of Srpska failed to comply with an explicit provision of the Constitution of the Republic of Srpska (1992), which prescribes the procedure for the protection of a vital national interest, according to which the votes of only two judges are sufficient to rule on the merits that a certain matter is a vital national interest ${ }^{23}$.

In fact, in its Rules of Procedure, the Constitutional Court of the Republic of Srpska stipulates that a two-thirds majority of the members of the Constitutional Court's Council for the Protection of a Vital National Interest (which consists of nine judges) is required for reaching a decision which states that a vital national interest is affected ${ }^{24}$. With this violation of the RS Constitution by the institution which should protect the constitutionality of all legal acts (including the said Rules), Bosniaks and Croats in the Republic of Srpska ${ }^{25}$ are put in an unfavourable position. In practice, the Council for the Protection of Vital National Interests very rarely adopted the requests for the protection of a vital national interest.

The ethnic key is considered in filling positions in all other state institutions in Bosnia and Herzegovina, but it also needs to be considered in filling judicial positions. In the Federation of Bosnia and Herzegovina, key positions of representatives in all branches of government at the federal level are constitutionally prescribed $^{26}$. Prime Minister/President of the Government of the Federation of Bosnia and Herzegovina and Deputy Prime Ministers cannot be from the same constituent peoples. Other key positions are: Chairman of the House of Repre-

\footnotetext{
${ }^{21}$ Article IV (3e) and f)) of the Constitution of Bosnia and Herzegovina. See also: Article 73, Article 74, Article 161 and other subsequent Articles of the Rules of procedure of the House of Representatives of the House of Representatives of the Parliamentary Assembly of Bosnia and Herzegovina, Official Gazette of Bosnia and Herzegovina, No. 33/06, 41/06, 91/06 and 91/07.

${ }^{22}$ Amendment XXXVII to the Constitution of the Federation of Bosnia and Herzegovina (1994), Official Gazette of the Federation of Bosnia and Herzegovina, No. 16/02 and Amendment LXXVII to the Constitution of the Republic of Srpska (1992), Official Gazette of the Republic of Srpska, No. $21 / 02$.

${ }^{23}$ Amendment LXXXII to the Constitution of the Republic of Srpska (1992), Official Gazette of the Republic of Srpska No. 21/02.

${ }^{24}$ Article 52 of the Rules of Procedure of the Constitutional Court of the Republic of Srpska, Official Gazette of the Republic of Srpska No. 29/05.

${ }^{25}$ According to the final results of 2013 census, Bosniaks make up $13.99 \%$ and Croats make up $2.41 \%$ in Srpska.

${ }^{26}$ Section D of Chapter IV of the Constitution of the Federation of Bosnia and Herzegovina (1994).
} 
sentatives of the Parliament of the Federation of Bosnia and Herzegovina, Chairman of the House of Peoples of the Parliament, President of the Supreme Court, President of the Constitutional Court and the Federal Prosecutor ${ }^{27}$. These six key positions in the Federation shall be filled along ethnic lines ${ }^{28}$ or the constituent status, and no more than two of them may be filled by members of the same constituent peoples. The legal and political problem is the fact that, under the Constitution of the Federation of Bosnia and Herzegovina (1994), President of the Constitutional Court, President of the Supreme Court and the Federal Prosecutor are appointed in accordance with the previously discussed post-election distribution of positions in the legislative body of the Federation, and the same goes for the appointment of Prime Minister, Chairman of the House of Representatives, and Chairman of the House of Peoples ${ }^{29}$. Thus, three of the key position in the Federation of Bosnia and Herzegovina are judicial positions and judicial positions should be filled in accordance with the principles of independence and impartiality of the judiciary. The other three positions are political and they have to be filled based on an agreement of political parties. It is evident from the cited provisions of the Constitution of the Federation of Bosnia and Herzegovina (1994) that the judicial office is subordinate to the political office. A particular problem is the fact that the mandate of judicial position holders is six years, while the mandate of political position holders is four years. The best solution to this problem would be to modify Articles IV (D.1.) and IV (D.1.a.) of the Constitution of Federation of Bosnia and Herzegovina by introducing special regulation of the distribution of judicial and political positions without the reciprocal links provided for in Article IV (D 1) of the Constitution of the Federation of Bosnia and Herzegovina (1994), which stipulates that elections for judicial positions will be held after the elections to the political office.

In the current practice of filling the positions in state bodies of Bosnia and Herzegovina, as a result of consociational democracy, the Republic of Srpska serves as a legitimacy base for the Serbs whereas the Federation of Bosnia and Herzegovina serves as a legitimacy base for the Croats and Bosniaks, although this is not a formal requirement. Particularly problematic is the ethnic criterion for the appointment of judges to the Constitutional Court. Although the Con-

\footnotetext{
${ }^{27}$ Article IV (D.1) of the Constitution of the Federation of Bosnia and Herzegovina (1994).

${ }^{28}$ The use of ethnic quotas is one of the key criteria for the distribution of power in the Federation Bosnia and Herzegovina, as is the case in the rest of the country. Article IV (B. 2) of the Constitution of the Federation of Bosnia and Herzegovina (1994) stipulates that the Government of the Federation of Bosnia and Herzegovina consists of a president and 16 ministers, namely eight Bosniak, five Croat and three Serb ministers. The government must be confirmed by a majority of the members of the House of Representatives. "The magic formula" is similar to the Swiss system and makes it impossible to form a majority/mono-ethnic government. One minister representing Others may be appointed by the Prime Minister from the quota of the largest constituent people. The government has a prime minister who has two deputies from different constituent peoples selected from among the ministers. After full implementation of Annex 7, at least $15 \%$ of members of the Government must come from one constituent people, at least 35\% of members of the Government must come from two constituent peoples and one member of the Government must come from Others.

${ }^{29}$ Article IV (D.1 a.) of the Constitution of the Federation of Bosnia and Herzegovina.
} 
stitution of Bosnia and Herzegovina contains a provision stipulating that, out of six members of the Constitutional Court, four are appointed by the House of Representatives of the Federation and two are appointed by the Assembly of the Republic of Srpska, the four members from the Federation have repeatedly been two Bosniaks and two Croats, and the two members from the Republic of Srpska have repeatedly been Serbs. This is an argument in favour of the claim that such a practice has created a constitutional custom which contains most of the characteristic of a custom secundum constitutionem (Balić, 200930).

\section{The Role of Political Parties}

In addition to the constitutional system, the political system Bosnia and Herzegovina also has blockade mechanisms and institutions. I can safely say that "multiparty unipartism" is on the scene in Bosnia and Herzegovina. Political parties operate as "enterprises". When it turns out that they cannot fulfil the promises they made to their voters before the elections, there is a discrepancy between what they said their aims would be and what they implement in practice ${ }^{31}$. After political parties win the elections, they divide the territory of the country and its wealth among themselves and then govern over "their" territory like medieval feudal lords $s^{32}$. Political parties in Bosnia and Herzegovina are predominantly mono-ethnic in nature, and in a multi-ethnic state such as Bosnia and Herzegovina they represent the interests of a single ethnicity, "their" own ethnic group (some of them declaratively advocate for state interests), and even if it were not used just as a cover-up for corruption and nepotism, it has long since become obsolete in modern states. Political parties in Bosnia and Herzegovina have to be democratised first, and then we can talk about increasing the level of democracy in Bosnia and Herzegovina.

The dysfunctionality of Bosnia and Herzegovina and the real equality of its constituent peoples do not stem from the Constitution alone and from inactivity of $\mathrm{OHR}^{33}$ and some other international institutions like IFOR/SFOR ${ }^{34}$; they are,

${ }^{30}$ Compare with: Kuzmanović (2002). Ustavno pravo, Banja Luka, Pravni fakultet, p. 508; Šarčević (1997) Ustav i politika (Kritika etničkih ustava i postrepubličkog ustavotvorstva u BiH), Ljubljana/Sarajevo, p. 53.

${ }^{31}$ For years, the political elites in Bosnia and Herzegovina have ruled the government without regard to the indifference of the people who live in this country, i.e. without fulfilling the election promises they made and carrying out the will of the people. In the previous four years, three separate events brought citizens from all over Bosnia and Herzegovina together, regardless of the entity they live in. These were: ID number protests in July 2013, workers protest in February 2014 (the "Bosnian spring", which had plenums of citizens as a consequence, but this model of direct democracy does not exist in any of the constitutions) and massive floods in May 2014.

${ }^{32}$ Society of Bosnia and Herzegovina in the period between elections really resembles to feudal society with all its customs and practices from top to bottom, where powerful political elites occupy a distinct position towards the working class. The working class in Bosnia and Herzegovina ("vassals") work much harder than the extremely rich politicians ("lords"), with little benefit or recognition. It is really hard for the workers to get more money or to move up in the social ladder, if they are not in some political party. Society does not allow for anyone to change its place because of its high corruption rate. Workers take care of their work place, because it is hard to be employed in post-Dayton Bosnia and Herzegovina, so they are afraid to report corruption.

${ }^{33} 2006$ has been a shift in the relationship of the international community, personified in the High Representative and the Peace Implementation Council, towards Bosnia and Herzegovina. Representatives of the international community have made a decision that the High Representative will no longer use the Bonn powers. It was ignoring the obligations of a legal nature concerning the security of implementation of this Dayton Peace Agreement, which is the fundamental role of the OHR, which is not derived from subsequently prescribed Bonn powers, but from the Annex 10 of the Dayton Peace Agreement.

${ }^{34}$ The implementation Force (IFOR) and the Stabilization Force (SFOR) were deployed in Bosnia and Herzegovina 1995-2004. One of the key duties of these international organisations-detention of persons who are suspects for a war crime was not achieved in more than a one decade after the signing of Dayton Peace Agreement. Very large number of persons suspected of war crimes were at large for a long time. 
to some extent, the result of the activity of the political parties in Bosnia and Herzegovina. Even though the provisions of the Constitution do not envisage it, as a result of political games in direct elections, political parties in the House of Representatives of the Parliamentary Assembly of Bosnia and Herzegovina apply the principle of ethnic instead of "entity" voting. If political entities behaved in a different way, the Republic of Srpska and the Federation of Bosnia and Herzegovina would not be able to block the forming of a government and hamper the passing of legislation. If the political parties operated in a different way throughout the territory of Bosnia and Herzegovina and tried to get a different support in terms of uniformity and support in both entities, in other words if the political terrain in Bosnia and Herzegovina were not divided based on "political parties from the Republic of Srpska" and "political parties from the Federation of Bosnia and Herzegovina", blockades could be avoided. The actual situation in terms of the composition of the House of Representatives could be avoided ${ }^{35}$ if political parties focused on the principle of the principle of constituent peoples throughout the country (seeking support in the other entity) more than on passing criticism about the Constitution of Bosnia and Herzegovina, particularly about its provisions regarding "entity voting"36.

\section{Weak Democratic Potential of Parliamentary Assembly of Bosnia and Herzegovina}

Parliamentary Assembly of Bosnia and Herzegovina does not perform the functions which are often within competence of a legislative body. It, for example, does not elect judges to the Constitutional Court, but this jurisdiction, paradoxically, belongs to entity parliaments, even though it deals with the election of members of state institutions. Parliamentary Assembly of Bosnia and Herzegovina also has no role in the election of candidates to judicial positions at the state level, since it is the competence of an independent institution-the High Judicial and Prosecutorial Council of Bosnia and Herzegovina. The democratic performance of the Parliamentary Assembly needs to be strengthened in terms of the legislative function (a revision of the Constitution, legislative initiative, public hearing, hearing and voting, relations between the houses of the Parliamentary Assembly of Bosnia and Herzegovina in a legislative procedure, shortened and emergency procedure and budget function), the control function (choice and vote of no confidence to the Council of Ministers of Bosnia and Herzegovina, the adoption of the budget, reports, representatives' questions, interpellation, investigation committees, public hearings and control over the sector of defence

\footnotetext{
${ }^{35}$ One of the main characteristics of the debate in Parliamentary Assembly of Bosnia and Herzegovina on constitutional amendments that was submitted in April 2006, was that there was a prevalent lack of knowledge about the constitutional solutions, which lead to certain constitutional categories defined in the proposed amendments being discussed as something that is quite new for the constitutional order of Bosnia and Herzegovina. Such was the situation, e.g., to the issue of entity voting, which was attacked and called a "gimmick", even though it already exists in the Constitution.

${ }^{36}$ It should also be noted that political parties in Belgium are created based on segments of culture manifested in linguistic groups, and there are no political parties at the federal level. However, in many federal states, national political parties represent an integrative force.
} 
and security), and the transparency of implemented activities (freedom of access to information and activity reports) (Marković, 2012).

The exercise of the functions of the Parliamentary Assembly is conditioned by a domination of ethnic political elites (except in the period from 2000 to 2002 (Trnka et al., 2009)) and large political coalitions. Opposition in the Parliamentary Assembly has so far, except in one session, been rare. None of the grand coalitions, which is always made up of political parties from all three constituent peoples, has had a programmatic character, which hindered decision making. Although it is possible that a political party in such a coalition represents the will of a single constituent people, this has not happened yet. A heterogeneous composition of a large coalition (the number of parties per convocation ranged between 11 - 17 parties (Trnka et al., 2009)) makes the term "parliamentary majority" very precise, i.e. the government and the opposition, since a parliamentary majority often cannot know for sure if its policies will be adopted and implemented or not. It influences the work of the Parliamentary Assembly, particularly the exercising of the legislative function and its relationship with the Council of Ministers. Although the Council of Ministers dominates the legislative process, proposed legislation in Bosnia and Herzegovina is passed less frequently than in other countries due to an unstable parliamentary majority. In addition, party discipline that binds the members of the Parliamentary Assembly and non-institutional arrangements of party leaders diminish the importance of the Parliamentary Assembly, which only formalises the political agreements reached at the meetings of party elites. In this way, party elites have made some of the most important decisions within the competence of the Parliamentary Assembly and thus decreased its credibility.

\section{Downsides of the Institutes of Direct Democracy}

In response to the elitism of consociational democracy, the constitutional system of Bosnia and Herzegovina could incorporate the institutes of direct democracy (Trlin, 2011). In comparative legal and political practice referendums are rare. Switzerland (Stojanović, 2007) could be a good role model. It is a federal state just like Bosnia and Herzegovina, and has a lot in common with Bosnia and Herzegovina (Duraković, 2010). In order for citizens to be able to directly decide at the state level, it is necessary to prescribe, in the constitution, the jurisdiction of the Parliamentary Assembly of Bosnia and Herzegovina over deciding on announcing a referendum. The Constitution of Bosnia and Herzegovina does not recognise direct democracy. Representative democracy (just like in Germany (Dauster, 2011)) dominates the decision-making process at the state level (Ademović, Marko, \& Marković, 2012). Since the Parliamentary Assembly makes a small number of decisions, I believe that the Constitution of Bosnia and Herzegovina needs to introduce a mandatory constituent referendum and a legislative referendum, but strictly for non-ethnic issues, where decisions made in a referendum could take effect only if the House Peoples of the Parliamentary Assembly of Bosnia and Herzegovina (Marković, 2009c) adopts them (this would 
be a kind of "limited referendum"). Amendments to the provisions on human rights (Annex 4) would not be subject to a vote, and this is the practice in comparative constitutional systems. Like in Switzerland, referendums would be initiated from the "bottom-up", i.e. by citizens who would put on the political agenda the matters that politicians ignore.

Direct democracy is a set of mechanisms in which the majority can impose its will on a minority, and in theory, it cannot not be advocated in multiethnic societies. An exception could be made if a law in Bosnia and Herzegovina would lay down that direct democracy cannot be used for matters which can affect a vital interest (it should also provide a definition of what this term actually means; I think the term a "vital ethnic interest" should be used instead, and it should include culture, language, religion and tradition), or major political issues (secession of a part of the territory of Bosnia and Herzegovina, or abolishment of entities).

History teaches us that a referendum in a federal state can result in tensions among ethnic groups (a national referendum on the "royal question" in Belgium or independence referendums in former Yugoslavia in the early 1990s). All changes to the constitution should be subject to a decision of a qualified majority, and such a decision would imply a constituent referendum (e.g. for constitutional amendments, approval of the majority of citizens of Bosnia and Herzegovina $(50 \%+1)$ and at least $35 \%$ of citizens in each entity could be the requirement; for referendums in the Federation of Bosnia and Herzegovina, a qualified majority could require a majority of citizens and a majority in at least eight (out of ten) cantons. This is an additional guarantee for the minorities that such a reform will not be made without their consent.

Direct democracy in Bosnia and Herzegovina should be introduced in the local government and regularly implemented. Nevertheless, its implementation at all levels of government should be seen as a slow and lengthy process. Following the introduction of potential changes to the Constitution of Bosnia and Herzegovina, a referendum carried out the way I described earlier on would result in strengthening the Bosnian demos (nation). Regardless of the fact that the Constitution lays down the existence of the Bosnian nation, these procedures would make it visible in practice. The repetition of a constitutional and legislative referendum at the state level, with ethnic groups participating in it, would create a sense of belonging to the same demos (nation) among them. Politicians would have to have a referendum campaign throughout Bosnia and Herzegovina and speak about the same issue at the same time in different areas of Bosnia and Herzegovina. Currently, Belgium has the same problem as Bosnia and Herzegovina; in the electoral process, its citizens, depending on the linguistic region they belong to, are discussing various political issues. Switzerland does not have this problem, precisely because direct democracy has softened it (Stojanović, 2009).

\section{The Role of the Constitutional Court}

An additional problem is that the Constitution of Bosnia and Herzegovina re- 
stricts the circle of subjects who may apply for a constitutional review. In principle, these are the same subjects that are involved in passing laws and other general acts (members of the Presidency, the Chair of the Council of Ministers of Bosnia and Herzegovina, the Chair and Vice-Chairmen of both Houses of the Parliamentary Assembly of Bosnia and Herzegovina and a qualified number of members/delegates in legislative authority of the state, entities and Brčko District of Bosnia and Herzegovina ${ }^{37}$ ), so it is not surprising that there is a limited number of cases of abstract constitutional review falling within jurisdiction of the Constitutional Court of Bosnia and Herzegovina. The same problem occurs in the Constitutional Court of Federation of Bosnia and Herzegovina (along with the problem of a limited number of matters falling within jurisdiction of this Court in reviewing the constitutional validity of legislation in Federation of Bosnia and Herzegovina (Milićević, 2013)): there is a very small number of subjects that usually have no interest in initiating proceedings to review the constitutionality of laws or regulations, since they were, in some way, involved, in some stage of the adoption of these acts. It is the innermost circle of holders of leading positions in the federal and cantonal executive branch or the subjects of the federal or cantonal legislative body which passes laws. The circle of authorised entities initiating proceedings before the Constitutional Court of Bosnia and Herzegovina and the Constitutional Court of the Federation of Bosnia and Herzegovina should be expanded to include the ones that exist in the constitutions of many other countries. In addition to the subjects cited in the Constitution of Bosnia and Herzegovina and the Constitution of the Federation of Bosnia and Herzegovina (1994), it would be necessary to give authorisation to institute proceedings before the two constitutional courts to the municipal and city councils and municipal mayors and mayors, when they consider that certain regulations are not in accordance with the Constitution or the law in terms of violation of the constitutional position of the municipality/city. Other organisations and communities should have this right when they believe that a general legal act is endangering their constitutional rights. In addition, the two constitutional courts should be given the authority to initiate proceedings regarding the constitutionality of laws or the constitutionality and legality of other regulations and general acts ex officio when they, in their practice, determine that a provision of a general legal act should be assessed in the prescribed procedure.

\section{The Rule of Law}

The House of Peoples comprises 15 delegates. Nine (9) members of the House of Peoples comprise a quorum, provided that at least three (3) Serb delegates (from the Republic of Srpska), three (3) Bosniak delegates (from the Federation of Bosnia and Herzegovina) and three (3) Croat delegates (also from the Federation of Bosnia and Herzegovina) are present. If all Serb (5) and all Croat delegates (5) vote in favour of a certain decision, and all Bosniak delegates vote against it, that decision can be adopted regardless of the fact that all Bosniak delegates voted

\footnotetext{
${ }^{37}$ Article VI (3a.) of the Constitution of Bosnia and Herzegovina.
} 
against it, because there is a majority of delegates present and voting, and the principle of "entity voting" is met since at least $1 / 3$ (2) delegates from the Republic of Srpska and at least 1/3 (3) delegates from the Federation of Bosnia and Herzegovina voted in favour of that decision. If all Croat delegates vote against a decision, all constitutional requirements are met. However, this is not the case with Serb delegates. If all five or only four Serb delegates in the House of Peoples vote against a decision, that decision cannot be adopted because the principle of "entity voting" has to be applied. If a decision was not adopted in the first round, the second round of voting takes place. In addition to having a majority of votes of delegates present and voting, the second round of voting requires that, among the delegates who voted against a decision, 2/3 (3) or more of them are not Serb delegates, that is $2 / 3$ (7) or more of them are not Bosniak and Croat delegates ${ }^{38}$. In this round, Croat or Bosniak (7) delegates cannot prevent the adoption of a decision whereas Serb (3) delegates can. The principle of "entity voting" results in inequality of the constituent peoples in decision-making in the House of Peoples, since Serb delegates can, without using the mechanism which protects their vital national interests, prevent the adoption of the decisions that are, in their opinion, contrary to their vital national interest. According to the Constitution $^{39}$, the protection of a vital national interest of Bosniaks and Croats can only be exercised by initiating proceedings before the Constitutional Court. But the problem lies in a possibility stipulated in the Constitution, according to which three judges who are not citizens of Bosnia and Herzegovina (they are members of the Constitutional Court) and judges who are not members of the constituent peoples whose vital national interest is being decided over can decide over whether a certain decision of the Parliamentary Assembly of Bosnia and Herzegovina affects a vital national interest of a certain constituent peoples or not (this Court decides by majority vote).

In Bosnia and Herzegovina, in the post-Dayton period, the number of laws which did not have entity support ${ }^{40}$ is far greater than the number of times the procedure for protection of the vital national interests during the process of passing laws was requested ${ }^{41}$. The representatives and delegates from the Republic of Srpska stopped the passing of certain laws by entity voting ${ }^{42}$ numerous times, but they never invoked the protection of a vital national interest. Ethnic voting is more frequently used at entity level, particularly in the Republic of Srpska, than at state level (Sahadžić, 2012). Even when democracy includes an abstract citizen, the ethnocratic element dominates over political procedures and the parliamentary decision-making system (Šarčević, 2010).

\footnotetext{
${ }^{38} \mathrm{Article}$ IV (3d.) of the Constitution of Bosnia and Herzegovina.

${ }^{39}$ Article IV (3f.) of the Constitution of Bosnia and Herzegovina.

${ }^{40}$ From 1997 to 2007, the Parliamentary Assembly of Bosnia and Herzegovina rejected a total of 260 laws, 156 of which were rejected based on "entity veto".

${ }^{41}$ For example, in the period from the creation of the Constitutional Court to 1 June 2012, only four proceedings to protect vital national interests of the constituent peoples were initiated. This can be explained by the fact that entity voting has the power of the absolute veto, and the Constitutional Court takes part in the procedure for protection of a vital national interest. The Constitutional Court can rule that a law does not affect a vital national interest of a constituent people, and consequently that law will not come into effect.

${ }^{42}$ In the period from 1997 to 2007, representatives and delegates in the Parliamentary Assembly of Bosnia and Herzegovina from the Republic of Srpska used "entity veto" 136 times, and the deputies and delegates from the Federation of Bosnia and Herzegovina used it 20 times.
} 


\section{Conclusion}

The key aim of introducing the consociation model is to stabilize the political system. Consociational democracy is usually based on a power-sharing model. However, the rule of ethnic nationalism in Bosnia and Herzegovina, even twenty years after the Dayton Peace Agreement, seriously destabilizes the state. The implementation of the consociational model of democracy leads to the exclusion of a large number of people from the decision-making process, so the objection of lower level of democracy compared to other models of democracy, can be given to this political regime. Instead of trying to compromise, political alliances that make up the consociation in Bosnia and Herzegovina often opt to create conflicts.

Elements of consociation existed in the first and second Yugoslavia (in the second Yugoslavia, they include: "brotherhood and unity", the delegate system, the parliament comprising five chambers). Collective representation should exist, but exclusive ethnic representation (in Bosnia and Herzegovina, the ethnic principle coincides with the religious identity), which excludes certain collectives from the decision-making process, is not in accordance with the rule of law and the prohibition of discrimination and domination. If certain individuals in Bosnia and Herzegovina think that they are discriminated against, the substitute for the use of collective protection mechanisms could be the administrative and judicial protection provided by the Anti-Discrimination Act of Bosnia and Herzegovina, which makes it possible for individuals to try to prove that they were discriminated against. In this way the decision-making process in Bosnia and Herzegovina could be accelerated. In addition, the decision making process in Bosnia and Herzegovina could be made more efficient by opening up the constitutional system of Bosnia and Herzegovina to the principles of direct democracy. Switzerland can serve as an example of comparative federalism in which direct democracy hampers the existing animosities among different cultural segments.

The citizens of Bosnia and Herzegovina do not play a significant role in the society of Bosnia and Herzegovina. The Constitution of Bosnia and Herzegovina has made citizens, together with the constituent peoples, the bearers of sovereignty; however, it has not provided them with the mechanisms of governance, except in the House of Representatives. Even though citizens are represented in the House of Representatives, instead of bringing citizens to the forefront of the decision-making process entity voting has done that with ethnic groups. The political system disregards the citizens and places the political elites at the forefront.

Direct democracy is not incorporated in the Constitution of Bosnia and Herzegovina so as to allow the citizens to exercise power and weaken the orders of the political elites which often do not serve the public or act in the general interest of the public. It is not incorporated in the laws of Bosnia and Herzegovina. Moreover, it also is non-existent at the level of government of the Federation of Bosnia and Herzegovina. Direct democracy only exists in the Constitution of the 
Republic of Srpska (1992) and in the laws of the local government. A broad regulation of direct democracy is a precondition for its implementation. Furthermore, since direct democracy today is widely set up only in the legal framework of a local government, it should be practiced "bottom-up".

Democracy can exist if people cannot elect officials and then control them. Therefore, plenary sessions that were held after the "Bosnian Spring" should also be incorporated in legal documents. This becomes even more obvious if we bear in mind that it is a notorious fact that politicians in Bosnia and Herzegovina only represent their own political party; they neither -represent a single people nor citizens for that matter. In this regard, a recall of elected officials should be incorporated in the legal system as a mechanism in which people would be able to rate the work performance of the elected representatives as unsatisfactory and thus remove them from office. This would strengthen the politicians' accountability to the electorate and it would create the basis for a permanent legal and political relationship between voters and their elected representatives. In this way, the elected representatives' work performance could be evaluated not only during the elections but at other times as well.

The perspective offered from the beginning of this paper is to present the characteristic and characteristic problems of the democratic constitutional system of Bosnia and Herzegovina. The analysis carried out in the article brings out the need of incorporating, at least in certain amount, the model of participatory democracy (its political aspect; economic aspect is not discussed in this article). Although the future of Bosnia and Herzegovina's political regime is certain at the moment, one thing is clear: discontent of citizens, and the state relations between certain lower political-territorial units, allow us and future researchers to propose the advancement idea of inclusion of participatory democracy in constitutional system of Bosnia and Herzegovina all other sub-constitutional systems where it has not been included. Constitutional system of Bosnia and Herzegovina really is an interesting field of research for the scholars which scientific interest is constitutional law and international public law, so this paper is a contribution to the science of these two branches of the law. The deficiency of the article could be the lack of literature in English language on the topic of the article, and the fact that each of these limiting factors of democracy in Bosnia and Herzegovina could be a topic of separate papers. Hopefully, there would be other researchers to explore some of these limitations which are previously analyzed in the paper.

\section{References}

Ademović, N., Marko, J., \& Marković, G. (2012). Ustavno pravo Bose i Hercegovine. Sarajevo: KAS.

Annex IV to the General Framework Agreement for Peace.

Balić, L. (2009). Ustavni obićaj u Bosni i Hercegovini-Osvrt na izbor sudija Ustavnog suda Bosne i Hercegovine. In Godišnjak Pravnog fakulteta u Sarajevu (pp. 13-25). Sarajevo: Univerzitet u Sarajevu.

Belloni, R. (2004). Peacebuilding and Consociational Elecotral Engineering in Bosnia and 
Herzegovina. International Peacekeeping, 11, 334-353.

https://doi.org/10.1080/1353331042000237300

Bieber, F. (2004). The Challenge of Institutionalising Ethnicity in the Western Balkans: Managing Change in Deeply Divided Societies. European Yearbook of Minority Issues, 3, 89-107. https://doi.org/10.1163/221161104X00066

Bose, S. (2002). Bosnia after Dayton. London: Nationalist Partition and International Intervention.

Constitution of the Federation of Bosnia and Herzegovina (1994).

Constitution of the Republic of Srpska (1992).

Dauster, M. (2011). Narod odlučuje-Direktna demokratija u Njemačkoj: Pregled kao razmišljanje za Bosnu i Hercegovinu. Sveske za Javno Pravo, 6, 62-80.

Duraković, N. (2010) Uporedni politički sistemi. Sarajevo: Fakultet političkih nauka.

European Commission (2010). Bosnia and Herzegovina and 2010 Progress Report (p. 5). SEC 1331.

Kulenović, N., Hadžialić-Bubalo, I., \& Korajlić, M. (2010). Presuda Sejdić i Finci protiv Bosne i Hercegovine Konkretne posljedice-Prvi pregled. Sveske za Javno Pravo, 1-2, $18-36$.

Kuzmanović, R. (2002). Ustavno pravo. Banja Luka: Pravni fakultet.

Lijphart, A. (1977). Democracy in Plural Societies: A Comparative Exploration. New Haven, CT: Yale University Press.

Marković G. (2009b). Demokratija na bosanski način. http://pescanik.net/demokratija-na-bosanski-nacin/

Marković, G. (2009a). Demokratija i Ustav Bosne i Hercegovine: Studija o neposrednoj demokratiji i radničkoj participaciji u BiH sa prijedlozima amandmana na Ustav Bosne i Hercegovine. www.direktnademokratija.net

Marković, G. (2009c). Federalizam u ustavnom sistemu Bosne i Hercegovine. PhD Thesis, Beograd: Beograd University.

Marković, G. et al. (2012). Poboljšanje demokratskih perfomansi Parlamentarne skupštine Bosne i Hercegovine-Preporuke. Sarajevo: Sarajevski otvoreni centar.

Milićević, N. (2013). Problemi i mogućnosti promjena u ustavnom sistemu BiH. In Godišnjak Pravnog fakulteta u Sarajevu (pp. 143-160). Sarajevo: Univerzitet u Sarajevu.

No. U-14/12 (2015). Decision of the Constitutional Court of Bosnia and Herzegovina.

Official Gazette of Bosnia and Herzegovina, No. 33/06, 41/06, 91/06 and 91/07. Rules of the Procedure of the House of Representatives of the Parliamentary Assembly of Bosnia and Herzegovina.

Official Gazette of the Republic of Srpska No. 29/05. Rules of Procedure of the Constitutional Court of the Republic of Srpska.

Pobrić, N. (2000). Ustavno pravo. Mostar: Slovo.

Sahadžić, M. (2012). "Veto mechanism" in Parliaments on the State and Entity Level in Bosnia and Herzegovina. In S. Gavrić, \& D. Banović (Eds.), Parliamentarism in Bosnia and Herzegovina (pp. 293-323). Sarajevo: Sarajevski otvoreni centar.

Šarčević, E. (1997). Ustav i politika (Kritika etničkih ustava i postrepubličkog ustavotvorstva u BiH). Ljubljana/Sarajevo.

Šarčević, E. (2009). Dejtonski ustav: Karakteristike i karakteristični problem (pp. 60-61). Sarajevo: KAS.

Šarčević, E. (2010). Ustav iz nužde. Sarajevo: RABIC.

Stojanović, N. (2007). Konsocijacija-Švicarska i Bosna i Hercegovina. Pregled, 85, 63-87. 
Stojanović, N. (2009). (Ne)moguća reforma u Bosni i Hercegovini? Iz konsocijacijske ka direktnoj demokratiji. Puls Demokratije (see also, in English, Bosnia Daily, 22 December, pp. 8-9).

Trlin, D. (2011). Problem referenduma u BiH. Sveske za Javno Pravo, 6, 55-62.

Trnka, K. et al. (2009). Proces odlučivanja u Parlamentarnoj skupštini Bosne i Hercegovine (p. 142). Sarajevo: KAS.

$\mathrm{UN} \mathrm{BiH}$ and UN OHCHR. Compilation of Recommendations of the UN Human Rights Bodies, Bosnia and Herzegovina.

Venice Commission (2005). Opinion of the Venice Commission on the Constitutional Situation in Bosnia and Herzegovina and the Powers of the High Representative (pp. 9-12). CDL-AD 004.

Venice Commission (2006). Opinion of the Venice Commission on the Draft Amendments to the Constitution of Bosnia and Herzegovina. CDL-AD 019.

Submit or recommend next manuscript to SCIRP and we will provide best service for you:

Accepting pre-submission inquiries through Email, Facebook, LinkedIn, Twitter, etc. A wide selection of journals (inclusive of 9 subjects, more than 200 journals)

Providing 24-hour high-quality service

User-friendly online submission system

Fair and swift peer-review system

Efficient typesetting and proofreading procedure

Display of the result of downloads and visits, as well as the number of cited articles

Maximum dissemination of your research work

Submit your manuscript at: http://papersubmission.scirp.org/

Or contact blr@scirp.org 